\title{
Value education in the Polish family
}

The attitudes of the young generation, to a large extent, reflect tendencies prevailing in society. Unfortunately, at the beginning of the $21^{\text {st }}$ century in the Polish social reality there is a chaos of values, which dominates the political sphere, the mass media as well as education. This entails axiological disorientation of the young generation, which gradually loses the sense of the core values. In this case, children and youth particularly need wise and responsible parents who will help them in the process of building a system of values and reaching personal maturity. A child gains the basics of axiological education in a family that brings it up every day to cognition, choice, interiorization and realization of values, adhering to the principle of

* Elżbieta Osewska - a habilitated doctor of Theology in the field of Catechetics and a professor of the State Higher Vocational School in Tarnow. In 1990-1993 she was a lecturer in educational and catechetical centres in the former USSR. In 1998-1999 the Head of the Family Affairs Department in the Prime Minister's Office in Warsaw. From 1999 to 2014, a consultant in the Teacher Training Centre in Łomża. In 1995-2015, an academic of the Cardinal Wyszyński University in Warsaw and since 2015 - of the State Higher Vocational School in Tarnow. An expert of the Polish Accreditation Committee, and Équipe Europea di Catechesi (EEC), the President of the Polish Section of the European Society for Catholic Theology (ESTK), the President of the Polish Familiology Association, a member of the European Forum for Religious Education in Schools (EuFRES) and the Association of Polish Catechetic Teachers, an author of publication in the field of pedagogics, teaching, catechetics, pastoral theology, interpersonal communication and family politics; an organizer and participant of numerous catechetical conferences and congresses in Poland and abroad. 
child's subjectivity. It is worth mentioning that despite the emerging crisis of a family in Poland, the family model based on a marriage with children ${ }^{1}$ still dominates, which gives better opportunities for providing value education. In this article, the value education in a Polish family will be presented, with the indication of the family's orientation to the world of values, the emphasis of educational personalism, the portrayal of stages of value education and the current determinants of this education.

\section{Orientation to the world of values}

Value is one of the basic terms that is a subject to philosophical, social and pedagogical reflection. It is hard to point out such philosophical system which would not, in some way, deal with this issue, promoting some values, introducing their particular hierarchy or pointing to the lack of them. ${ }^{2}$ The issue of selection, classification and realization of values is not purely an academic discussion of little practical value. The consequence of the lack of attention given to values is confusion in modern axiological reflections. ${ }^{3}$ Postmodern philosophy globally undermines the entire ethics because its theorists are not only against certain moral systems but simply aim to destroy ethics. ${ }^{4}$ The hierarchical system of goods can be only spoken about on the ground of non- axiological criteria which are in connection with some particular mental, intellectual and technical dispositions of an individual. ${ }^{5}$ Only attempts to describe a relation between values are made here, leaving out their definition while the entire issue is come down to the choice between different objectives. It is assumed that preferences are determined intuitively or even emotionally. A thing becomes good only when it is subjectively

1 Cf. Główny Urząd Statystyczny, Gospodarstwa domowe i rodziny. Narodowy Spis Powszechny Ludności i Mieszkań 2002, Warszawa 2003, p. 28; Główny Urząd Statystyczny, Rocznik demograficzny 2003, Warszawa 2003, p. 136.

2 Cf. R. Darowski, Filozofia człowieka, Kraków 1992, p. 100.

3 Cf. P. Marczuk, Problemy klasyfikacji wartości, "Studia Filozoficzne" 6 (259) (1987), p. 81.

4 Z. Sareło, Postmodernistyczny styl myślenia i życia, in: Postmodernizm. Wyzwanie dla chrześcijaństwa, Poznań 1995, p. 15; Wychowanie a wyzwania ponowoczesności, red. E. Osewska, Warszawa 2011.

5 Cf. P. Dziamski, O racjonalności wartości, “Człowiek i Światopogląd” 4 (1980), p. 65. 
recognized as such by someone. ${ }^{6}$ Proponents of such stance recognize as a value only something that meets certain needs of a person, forgetting that the reality itself demands a value. ${ }^{7}$ Additionally, a thesis on the conflictual nature of values, along with the belief of the impossibility of their justification, plays after all a "useful" role. Due to being enigmatic, it makes it easier to abandon more difficult values for the sake of easier ones.

The youngest generation who is just building their identity is in a particularly difficult situation. A sense of a loss of values, the disintegration of valuation and the difficulties associated with adolescent crisis require reliable reference points: persons, beliefs, attitudes and rules. The important reference point is society with its permanent, verified ideals, preferences and criteria of evaluation. ${ }^{8}$ In this sense, the current situation may be described as a situation between the paradise and a catastrophe since on the one hand, the mainstream media promote a modern, utopian lifestyle while on the other, a young person has a sense of loss and loneliness, a disorder of values, which may lead them to a disaster.

Values shape a person's identity. Due to them the questions like "who am I," "where am I going," "what is the purpose of my life" can be answered. A search for identity means here to a large extent "becoming who one essentially is," someone fully human, an individuality or an authentic person. Before any axiology trying to find criteria that help arrange values, there are serious difficulties, primarily in finding their hierarchy. ${ }^{9}$ The Christian position assumes that values, depending on the place they occupy in the hierarchy, have a particular appeal, demand their implementation, almost "cry" for the subject's reaction, for the proper attitude to them..$^{10}$ The role of values in lives of children and youth creates for a family a need to take value education, in its broadest sense. For it is the family that is the primary environment of the development and education of a person. It is the family where a person lives for the most important and the longest period in which their identity,

6 Cf. W. Stróżewski, Istnienie i wartość, Kraków 1981, p. 31.

7 Cf. W. Stróżewski, W kręgu wartości, Kraków 1992, p. 109.

8 Cf. K. Denek, Aksjologiczne aspekty edukacji, Toruń 1999; R. Jedliński, Świat wartości uczniów kończących szkołę podstawową, Kraków 1998; K. Chałas, Wychowanie ku wartościom, Lublin-Kielce 2003; M. Łobocki, W trosce o wychowanie w szkole, Kraków 2007.

9 Cf. W. Stróżewski, Istnienie i wartość..., pp. 24-27.

10 Cf. A. Szostek, Wokót godności, prawdy i miłości, Lublin 1998, p. 101. 
lifestyle and the way they view the world develops. Other environments are secondary and they either strengthen the family's influence, or modify and supplement it. ${ }^{11}$ The family creates a special system of a joint action. In it, each member has their duties to fulfil but everyone participates in them.

\section{Personalist value education}

Values exist in the relation to its subject - the person who has personal greatness and dignity. Each person, even the one with disability, illness or weakness, must be seen as a human being created by God and oriented to Him. ${ }^{12}$ A person, in their individuality, is never a number, they cannot be reduced to an item that can be destroyed. ${ }^{13}$ Anthropology built on the foundation of personalism rejects any separatist portrayal of a person that understands the relation between their spiritual and physical sphere in an excessively dualistic way. In consequence, this leads to a very critical look at the human body. "A person" does not fit into the concept of "an individual of a species" but contains something more in itself - a special fullness and perfection of existence. ${ }^{14} \mathrm{~A}$ person is a coexistence of two seemingly opposite elements - the spiritual and the material, that nevertheless form a unity.

In the personalist vision, a human - as the person who is capable of living in awareness and freedom - is able to understand oneself and the world and to take a responsible attitude towards oneself, other people and society. A human remains a free person, able to make choices, but not perfect. From the theological perspective, he/she is weakened by internal and external evil. That is why value education in the family is not a natural and spontaneous process but requires a mature presence of parents and the child's internal discipline and effort. The core values, on which education in the family should

11 Cf. Z. Skorny, Psychologia wychowawcza dla nauczycieli, Warszawa 1992, p. 33.

12 Cf. I. Obuchowska, Wychowanie dzieci niesprawnych umysłowo - dzieci upośledzone umysłowo w stopniu lekkim, in: Dziecko niepetnosprawne w rodzinie, red. I. Obuchowska, Warszawa 1991, p. 201.

13 Cf. C. Bartnik, Personalizm, Lublin 1995, p. 189; J. van der Vloet, Obraz człowieka jako fundament pedagogii, in: Pedagogika katolicka. Zagadnienia wybrane, red. A. Rynio, Stalowa Wola 1999, pp. 37-44.

14 Cf. K. Kołodziejczyk, Etyka społeczna Karola Wojtyły, Toruń 2000, pp. 9-11. 
be based, is responsible love and objective truth about the person..$^{15}$ Values that in personalist pedagogy are the basis of education: truth and love, good and beauty, faith and hope, fidelity and responsibility as well as holiness and salvation give a perspective of a wise education in the family and preschool.

A small child, as a person, is characterized by a specific activity through which it reveals its uniqueness and individuality. However, the child's own activity, in its early days, needs some guidance. Parents, guardians, grandparents, older siblings should support the subjective symptoms of the child's action and activity by creating appropriate conditions of its accomplishment, stimulation and guidance of its symptoms so that the space of the child's self-activity widens along with its growth.

In the family's modern environment, very important symptoms of the child's self-activity are playing and inquiry. Playing allows the child to freely express its emotions, engage creatively, practise new skills, develop mental and physical abilities, and is a preparation for future social roles. ${ }^{16}$ Responsible parents support this dynamic and educational development of the child's play by allowing it to play (appropriate space and toys) and stimulating it (showing interest, joining the play, providing hints and tips on the topic of the play). The time in which the child plays is an excellent opportunity to explore, experience, internalize and implement values. Themed activities are particularly valuable as they induce the child to make simple decisions, e.g. how to take care of a toy, how to help someone who is sick, what to choose in a situation of a dilemma about core values. The task of adult members of the family is to diagnose and support the child's moral development. Experiencing values, e.g. joy, love, respect, beauty, good, responsibility and hope, during play is extremely valuable.

Gradually, the child starts inquiring which involves to a greater extent a cognitive element. Supporting the child's inquiry by parents is expressed in the acceptance of the child's collections, taking it for a walk, answering its questions and joining in search for answers. Through questions, conversation, child's dilemmas, children have a chance to express their perceptions, thoughts and adopted values, and to gradually build their own system of values.

15 Cf. M. Dziewiecki, Wychowanie $w$ dobie ponowoczesności, Kielce 2002, pp. 213-226.

16 Cf. P. Kunowski, Podstawy współczesnej pedagogiki, Łódź 1971, pp. 225-239. 
Referencing to role-models and authorities will be beneficial for educating the child to values. It would be best if the value advocate was a person who is emotionally significant and from the immediate environment of the child. Parents, grandparents, guardians, educators must be aware that they represent a certain world of values which is watched and often mimicked by the child. Literary and film heroes, or saints may be also value advocates on condition that they are portrayed in a realistic way, they are not embellished or retouched. The idea is that the presented persons be reliable for children who are so sensitive to the truth.

\section{Stages of value education}

Adult members of the family make attempts that the young generation will accept the system of values adopted by them. ${ }^{17}$ They often assume that they have deepened knowledge, life experience and competences they can share with their children. Parents, grandparents, and guardians try to transmit to children and youth values they regard worthy and indispensable in life. However, in family value education, the sole transmission of values seems to be insufficient. A longer process is required that will help the child to understand, interiorize and to voluntarily and conscientiously acknowledge educationally-desirable values as their own and then to implement them in the child's life.

A few stages can be distinguish in this family process of value education. They include unravelling values as well as living, interiorizing and internalizing them. Each stage has its meaning and the sequence of stages must be observed ${ }^{18}$.

The first stage - unravelling values is an initial stage of getting to know, naming and understanding them. A child may recognize something as

17 Cf. J. Stala, E. Osewska, Anders erziehen in Polen. Der Erziehungs- und Bildungsbegriff im Kontext eines sich ständig verändernden Europas des XXI. Jahrhunderts, Tarnów 2009; J. Stala, Familienkatechese in Polen um die Jahrhundertwende. Probleme und Herausforderungen, Tarnów 2008; J. Stala, W kierunku integralnej edukacji religijnej w rodzinie. Próba refleksji nad nauczaniem Jana Pawła II w kontekście polskich uwarunkowań, Tarnów 2010; The contemporary family: local and European perspectives, eds. E. Osewska, J. Stala, Kraków 2015; Religious education/catechesis in the family. A European perspective.

18 See K. Olbrycht, Wychowanie do wartości - w centrum aksjologicznych dylematów współczesnej edukacji, "Pedagogia Christiana" (2012) nr 1/29, pp. 97-100. 
important and valuable for parents but it lacks appropriate vocabulary. Therefore, a simple and communicative language that allows naming and explaining values and talking about them is needed in the family community. This stage is conditioned with abilities of recognizing values through naming them but also understanding their sense based on credible explanation and demonstrating reliable examples of their implementation.

Regrettably, contemporary parents more than the previous generation are afraid of speaking openly about values and determining clearly what can and what can't be regarded as valuable. They often fear that their unambiguous attitude to values may be regarded by the younger generation as imposing, moralism or pompousness. Additionally, the media message through films, songs and games intended for children and youth reinforces the notion that even if objective values exist, they can be rejected is specific situations so that a human can achieve the intended objective. Novels, fables and fairy tales that showed unambiguously the victory of good over evil, the truth over a lie, nobleness over fraud have been replaced by cartoons in which the hero wins if he shows smartness, usefulness and adaptability to the situation while values are treated as naïve idealism. The reduction of reading books by children and youth for the benefit of a visual and audio message makes young people lack appropriate vocabulary to talk about unravelled values. The reduction of the set of required school readings, their substitution with watched films or summaries of prescribed texts make the young generation does not to know either appropriate terms or situations, history and events on the basis of which they could unravel values, learn how to think about them, value them and confront with others. In the family life we need time for a common discussion about a hero of the film, book or even the comic strip, game or series and making an effort to point out what principles he/ she followed in his/her behaviour, what he/she wanted, what was worthy for him/her; whether this can be recognized as values that all members of the family would like to follow.

Getting to know and understanding values requires their direct cognition in contacts with people who implement them. A child and a young person needs a contact with role-models. Therefore, in the family circle it is worth making references to people who are regarded value advocates, bot to living and dead ancestors. It is worth telling family stories, referring to examples of these family members who were in favour of specific values. Examples 
taken from family stories have an additional positive aspect, link the child to the family's past and help it to discover themselves as a continuator if values. Education to values needs to make references to specific examples of valuebearing people, attitudes and activities.

However, exclusively intellectual discovery and recognition of values is not enough. It is also important to live them, which is the second stage. In the family community in day-today situations it is important to arouse emotions and to connect them to specific values. An experience deepens an interest in given values, saturates them with an emotional content, makes them become intimate. Some situations reveal in a natural way in the family life, others require some involvement in the recognized values. The experiences daily life situations of an offered help, a joint preparation of a meal, a jointly performer work allow us to experience the values of love, dedication, good, respect, gratitude and responsibility. The same strong impact is exerted by various forms of family rituals, joint celebration and spending leisure time.

It is important these are not only superficial emotions appealing mainly to game and entertainment experiences but that an experience will go beyond more fundamental needs and values, and refer to higher values. Vital values such as health, food, activity, exercise and leisure have their value. However, to remain attached only to them may hinder the quest for higher values such as conscientiousness, honesty, honour, community, work, responsibility, composure, patience, courage, goodness, friendship, chastity, fidelity, independence, truthfulness, hard-working, kindness, forgiveness; and social values such as homeland, nation, the Church, patriotism, faith, hope and love. To remain attached only to lower values is the risk which parents who support their children in the education process succumb to.

Values familiarized with and lived in daily situations require their interiorization. It is most favourable for the interiorization to create situations for possible regular repetition of specific experiences that engage into the realization of a desired value. The acceptance of values and their frequent practice, the exercise of behaviours connected with them, their ever easier adoption are necessary so that they will interiorize in a young person. The continuous development of conditions favourable for their practice and the incentive for their regular realization require from parents and other adult members of a family a lot of patience, perseverance and consistency so as 
not to become disheartened in face of failures but rather to take action again and again and develop conditions for their realization.

Values that have been acknowledged and interiorized become a determinant of a young person's life. Therefore, the subsequent stage consists in the internalization of values that, when acknowledged as one's own, can be fully implemented in life. This stage requires both consistency and courage as well as responsibility to behave in each situation in accordance with acknowledged and adopted values. The whole family community and its individual members should support the young generation in regular realization of adopted values. It is very important to continually confirm the values implemented by children, to express respect and admiration for them, and responsibility for their presence and realization in the world ${ }^{19}$.

No other environment can substitute the educational activity of the family at all stages of value education. Regrettably, some families leave the process of value education to school or other institutions, making an assumption that it is a part of their duties. Nonetheless, without the family's participation and a constant cooperation with it, no institution will be able to take a child through subsequent stages of value education.

\section{Determinant of value education in the family}

In traditional societies there was a firm conviction about "true," "lasting" and "binding" values. They were proven and transmitted to subsequent generations by the family, Church, school and other educational institutions. Importantly, all educational institutions and the whole society transmitted the same values, what significantly strengthened value education.

In turn, in pluralistic societies different systems of values, also pseudovalues and anti-values, become apparent. The acquisition of the skill of discerning true values from pseudo- and advertised ones becomes the main problem. It seems that at present it is the mass media that are the most consistent transmitter of the system of "own values." They control the world of values of the young generation and adjust it to their own, most often consumption, objectives. They influence the acquisition of values,

19 K. Chałas, Wychowanie ku wartościom, Lublin-Kielce 2003. 
teach the desirable language of valuations, give their own media models, manipulate emotions and experiences, train desirable behaviours and attitudes. Recognizing both opportunities and threats of the current social and educational context, as far as value education is concerned, the family may not adopt an attitude of withdrawal and passing the buck to educational institutions. A simple transmission of values through giving children and young people a given system of values and watching over that it will be interiorized is not enough, either. ${ }^{20}$

The family is the first environment of a human's growth. It is the family where their personality, lifestyle and outlook on the world. For life in the family includes a long period and starts before other environments appear in a human's life. Therefore, it has chances - as the first - to show the world of values, teach appropriate language, explain, motivate, engage emotionally, check every day the realization of adopted values, confirm desirable attitudes. Additionally, family members are linked to each other in a particularly intimate manner as they are bound by blood and emotional relations. Other environments are merely secondary and either strengthen the family's influence or modify and supplement it. Family life and staying with people who we feel as emotionally close is also the source and foundation of varied social and emotional experiences. Therefore, in the family community, based on the foundation of love, it is much easier than in other environments to experience specific values and to implement them. ${ }^{21}$

In particular, at the beginning of the $21^{\text {st }}$ century, the young generation, living in an ever more individualized society is vulnerable to have their

20 Cf. H.-G. Ziebertz, Religijność i wychowanie w świecie pluralistycznym, Kraków 2001, p. 145.

21 Cf. J. Stala, Towards religious education..., p. 309-318; E. Osewska, To educate in a diversified Europe, „The Person and the Challenges“ 1 (2011) No. 1, p. 71-88; E. Osewska, The current situation of education and continuing professional development of RE teachers in Poland in the context of the social challenges, "The Person and the Challenges" 2 (2012) No. 2, pp. 123-131; J. Stala, E. Osewska, Sociological aspects of family religious education in Poland, in: Religious education/catechesis in the family. A European perspective, pp. 167-177; E. Osewska, Catechesis in the Polish family - an empirical survey, in: Religious education/catechesis in the family. A European perspective, pp. 179-192; E. Osewska, Education and Internet challenges, in: Education and creativity, ed. E. Osewska, Warszawa 2014, pp. 43-56; E. Osewska, The basic assumptions of child upbringing in the family. Modern implications, in: The contemporary family: local and European perspectives, pp. 249-261. 
hierarchical system of values shaken ${ }^{22}$ and to be guided by the belief that the standard for a human's proceedings is their subjective conscience, individual experiences and feelings. ${ }^{23}$ The theory of individualization, which points to the fundamental changes in an individual's interactions with society, putting the individual in the "centre" of the world gains in importance. In such a situation, the family community in which each member is driven by love, respect and responsibility for others, gives a chance to transcend subjective individualization and being governed by needs and values of the whole family community. ${ }^{24}$

The process of value education in the family is affected by the family structure itself, especially the fact of having or not both parents, their age, involvement in education, profession and social status, contacts with grandparents and older siblings. Value education in a two-generation family goes different than in a family composed of parents, grandparents and other household members. The best conditions for value education are provided by a conjugal family, consisting of mum, dad and children, in which both mum and dad are valuable persons, aware of their marital and parental duties. In a family with a few or at least with two children there are bigger opportunities to learn protectiveness, cooperation, agreeing one's needs and expectations with others. Regrettably, the only child is deprived of such opportunities. It is worth remembering that a family is a family due to an exceptional strength of bonds that are created in it; it can be a community that gives he sense of security, love and happiness, but for the same reasons may be the place of strong traumas. A lack of love, warmth and acceptance are extremely wounding as they refer to relations with the loved ones. In such a situation the process of value education will be greatly weakened and sometimes - damaged because it is difficult to accept values proposed by parents in a situation of excessive severity and a lack of emotional support.

22 Cf. K. Olbrycht, Dlaczego boimy się wartości w wychowaniu?, "Edukacja i Dialog" 2 (2000), p. 27; J. Bagrowicz, Godność osoby fundamentem wychowania, in: Wychowanie na rozdrożu. Personalistyczna filozofia wychowania, red. F. Adamski, Kraków 1999, p. 112.

23 Cf. P. Dziekoński, Współpraca nauczyciela z rodzicami przy aktualnym stanie rozwoju edukacji szkolnej, in: W poszukiwaniu katechezy rodziców. Studium teoretyczno-empiryczne. Problemy i wyzwania, red. J. Stala, E. Osewska, Tarnów 2007, pp. 276-277.

24 Cf. J. Mariański, Kryzys moralny czy transformacja wartości? Studium socjologiczne, Lublin 2001, pp. 79-85. 96. 331-374. 
In the post-modern society, in which there is pluralism of values and there is no commonly recognized value, the young generation may feel lacking axiological foundations. In such a situation, in the family community it is necessary to start a reflection on these attitudes and standards that collide with the unity of thoughts, emotions and will when taking decisions. Through common explanations, values and anti-values are subject to criticism and only then accepted and consciously acknowledged again. Children and young persons are invited by parents to check consequences and inconsequences of their choices. This way the process of consolidation of the acquired values, opening up to new choices and shaping attitudes whilst preserving the subjectivity of a young person.

The issue of value education in the family should be viewed in the context of the contemporary civilization that is now facing its crisis reflected first of all in a crisis of standards and values. In this context, parents, guardians, grandparents and other adult family members that take up value education face a very difficult task because an awful lot of external factors, while affecting the family itself, is weakening the process of education. Thus, wisdom, responsibility, patience and consistency are needed to - contrary to a chaos of values being imposed by the post-modern culture - undertake successive stages of young generation's value education. The awareness of the multitude of external factors that negatively impact value education in the family may not lead to pessimism and discouragement but to undertake a continuous educational work and to search for models of family value education.

\section{Bibliography}

Bartnik C., Personalizm, Lublin 1995.

Chałas K., Wychowanie ku wartościom, Lublin-Kielce 2003.

Darowski R., Filozofia człowieka, Kraków 1992.

Denek K., Aksjologiczne aspekty edukacji, Toruń 1999.

Dziamski P., O racjonalności wartości, “Człowiek i Światopogląd” 4 (1980), p. 65.

Dziewiecki M., Wychowanie w dobie ponowoczesności, Kielce 2002. 
Główny Urząd Statystyczny, Gospodarstwa domowe i rodziny. Narodowy Spis Powszechny Ludności i Mieszkań 2002, Warszawa 2003.

Główny Urząd Statystyczny, Rocznik demograficzny 2003, Warszawa 2003.

Jedliński R., Świat wartości uczniów kończacych szkołę podstawową, Kraków 1998.

Kołodziejczyk K., Etyka społeczna Karola Wojtyły, Toruń 2000.

Kunowski P., Podstawy współczesnej pedagogiki, Łódź 1971.

Łobocki M., W trosce o wychowanie w szkole, Kraków 2007.

Marczuk P., Problemy klasyfikacji wartości, "Studia Filozoficzne” 6 (259) (1987), p. 81.

Mariański J., Kryzys moralny czy transformacja wartości? Studium socjologiczne, Lublin 2001.

Nauki o rodzinie w służbie rodziny, red. J. Stala, Kraków 2014.

Obuchowska I., Wychowanie dzieci niesprawnych umysłowo - dzieci upośledzone umysłowo w stopniu lekkim, in: Dziecko niepełnosprawne w rodzinie, red. I. Obuchowska, Warszawa 1991, p. 201.

Olbrycht K., Dlaczego boimy się wartości w wychowaniu?, "Edukacja i Dialog" 2 (2000), p. 27.

Osewska E., Catechesis in the Polish family - an empirical survey, in: Religious education/catechesis in the family. A European perspective, eds. E. Osewska, J. Stala, Warszawa 2010, pp. 179-192.

Osewska E., Education and Internet challenges, in: Education and creativity, ed. E. Osewska, Warszawa 2014, pp. 43-56.

Osewska E., The basic assumptions of child upbringing in the family. Modern implications, in: The contemporary family: local and European perspectives, eds. E. Osewska, J. Stala, Kraków 2015, pp. 249-261.

Osewska E., The current situation of education and continuing professional development of RE teachers in Poland in the context of the social challenges, "The Person and the Challenges" 2 (2012) No. 2, pp. 123-131.

Osewska E., To educate in a diversified Europe, "The Person and the Challenges" 1 (2011) No. 1, pp. 71-88.

Pedagogika katolicka. Zagadnienia wybrane, red. A. Rynio, Stalowa Wola 1999.

Religious education/catechesis in the family. A European perspective, eds. E. Osewska, J. Stala, Warszawa 2010.

Sareło Z., Postmodernistyczny styl myślenia i życia, in: Postmodernizm. Wyzwanie dla chrześcijaństwa, Poznań 1995.

Skorny Z., Psychologia wychowawcza dla nauczycieli, Warszawa 1992. 
Stala J., Familienkatechese in Polen um die Jahrhundertwende. Probleme und Herausforderungen, Tarnów 2008.

Stala J., Osewska E., Anders erziehen in Polen. Der Erziehungs- und Bildungsbegriff im Kontext eines sich ständig verändernden Europas des XXI. Jahrhunderts, Tarnów 2009.

Stala J., Osewska E., Sociological aspects of family religious education in Poland, in: Religious education/catechesis in the family. A European perspective, eds. E. Osewska, J. Stala, Warszawa 2010, pp. 167-177.

Stala J., Towards religious education in the family in the $21^{\text {st }}$ century, in: The contemporary family: local and European perspectives, eds. E. Osewska, J. Stala, Kraków 2015, pp. 309-318.

Stala J., W kierunku integralnej edukacji religijnej w rodzinie. Próba refleksji nad nauczaniem Jana Pawła II w kontekście polskich uwarunkowań, Tarnów 2010.

Stróżewski W., Istnienie i wartość, Kraków 1981.

Stróżewski W., W kręgu wartości, Kraków 1992.

Szostek A., Wokół godności, prawdy i miłości, Lublin 1998.

The contemporary family: local and European perspectives, eds. E. Osewska, J. Stala, Kraków 2015.

W poszukiwaniu katechezy rodziców. Studium teoretyczno-empiryczne. Problemy i wyzwania, red. J. Stala, E. Osewska, Tarnów 2007.

Wychowanie a wyzwania ponowoczesności, red. E. Osewska, Warszawa 2011.

Wychowanie na rozdrożu. Personalistyczna filozofia wychowania, red. F. Adamski, Kraków 1999.

Ziebertz H.-G., Religijność i wychowanie w świecie pluralistycznym, Kraków 2001. 